\title{
Opportunities for reducing environmental emissions from forage- based dairy farms
}

\author{
Tom Misselbrook ${ }^{1}$, Agustin del Prado ${ }^{2}$ and David Chadwick ${ }^{1}$ \\ ${ }^{1}$ Rothamsted Research, North Wyke, Okehampton, Devon EX20 2SB, UK \\ ${ }^{2}$ BC3-Basque Centre for Climate Change, Alameda Urquijo 4, 48008 Bilbao, Spain \\ e-mail: tom.misselbrook@rothamsted.ac.uk
}

\begin{abstract}
Modern dairy production is inevitably associated with impacts to the environment and the challenge for the industry today is to increase production to meet growing global demand while minimising emissions to the environment. Negative environmental impacts include gaseous emissions to the atmosphere, of ammonia from livestock manure and fertiliser use, of methane from enteric fermentation and manure management, and of nitrous oxide from nitrogen applications to soils and from manure management. Emissions to water include nitrate, ammonium, phosphorus, sediment, pathogens and organic matter, deriving from nutrient applications to forage crops and/or the management of grazing livestock. This paper reviews the sources and impacts of such emissions in the context of a forage-based dairy farm and considers a number of potential mitigation strategies, giving some examples using

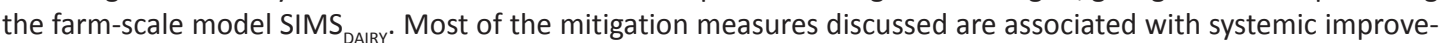
ments in the efficiency of production in dairy systems. Important examples of mitigations include: improvements to dairy herd fertility, that can reduce methane and ammonia emissions by up to 24 and $17 \%$, respectively; diet modification such as the use of high sugar grasses for grazing, which are associated with reductions in cattle $\mathrm{N}$ excretion of up to $20 \%$ (and therefore lower $\mathrm{N}$ losses to the environment) and potentially lower methane emissions, or reducing the crude protein content of the dairy cow diet through use of maize silage to reduce $\mathrm{N}$ excretion and methane emissions; the use of nitrification inhibitors with fertiliser and slurry applications to reduce nitrous oxide emissions and nitrate leaching by up to $50 \%$. Much can also be achieved through attention to the quantity, timing and method of application of nutrients to forage crops and utilising advances made through genetic improvements.
\end{abstract}

Key words: ammonia, diffuse water pollution, farm-scale model, greenhouse gas, mitigation

\section{Introduction}

The dairy sector, in common with other agricultural sectors, currently faces a great challenge to meet rising global food demands, particularly for livestock-derived food products, in a sustainable way (Godfray et al. 2010). There are important interactions between food production and other ecosystem services, including climate regulation, air and water quality, nutrient cycling, soil erosion, biodiversity and landscape quality, as discussed by Pilgrim et al. (2010) for temperate grassland systems, and the sustainable intensification of production relies on a good understanding of these interactions and our ability to identify potential 'win-win' strategies.

The assessment of such interactions for given management or mitigation scenarios on forage-based dairy farms was the primary aim of the development of the farm-scale SIMS ${ }_{\text {DARY }}$ model (del Prado et al. 2011). SIMS grates all of the major components of a dairy farm into a modelling framework using a system-based approach. It consists of modules dealing with overall farm management, herd nutrition and performance, field-scale flows of nitrogen $(\mathrm{N})$ and phosphorus $(\mathrm{P})$, livestock manure, economics and sustainability attributes. Specifically, SIMS quantitatively simulates the effect of interactions between farm management, climate and soil characteristics on losses of $\mathrm{N}, \mathrm{P}$ and carbon (C), including effects on farm profitability and giving a more qualitative indication of effects on biodiversity, milk quality, soil quality and animal welfare. While developed for UK dairy systems, and noting that outputs can vary depending on the model-scenario farm characteristics (particularly soil and climate), this can be used more generically as a useful tool in providing an assessment at the whole farm system level of the introduction of single or multiple mitigation methods, showing trade-offs between production and environmental effect, or between different environmental effects and identifying win-win scenarios. It is important that environmental effects are expressed per unit of production (e.g. litre of milk), i.e. an emission intensity metric, such that strategies leading to sustainable intensification of production can be identified as distinct from those which may reduce environmental impact at the expense of production. 
The aims of this paper are to give an overview of the potential environmental impacts to air and to water of predominantly forage-based dairy systems, to discuss some of the most promising potential mitigation strategies and to assess the impacts of a number of these using the farm-scale model SIMS DAIRY .

\section{Environmental impacts of dairy farms Emissions to the atmosphere}

The key emissions to the atmosphere of environmental concern from dairy farms are ammonia $\left(\mathrm{NH}_{3}\right)$ and the greenhouse gases methane $\left(\mathrm{CH}_{4}\right)$ and nitrous oxide $\left(\mathrm{N}_{2} \mathrm{O}\right)$. Other potential emissions of environmental concern include non-methane volatile organic compounds, fine particulates and heavy metals (Misselbrook et al. 2011), and while these may be of local importance in some instances such as around very intensive feedlots (e.g. Shaw et al. 2007), agriculture is generally not considered to be a major source for these species and they are not discussed further here.

Agriculture is the major source of $\mathrm{NH}_{3}$ emissions to the atmosphere, accounting for $>80 \%$ of total anthropogenic emissions in the UK (Passant et al. 2011), with the dairy sector accounting for approximately one third of total agricultural $\mathrm{NH}_{3}$ emissions. In a dairy farm context, $\mathrm{NH}_{3}$ emissions arise predominantly from the urea content of urine excreted by dairy cows, the urea being readily hydrolysed to ammonium in the presence of the ubiquitous enzyme urease. Emissions will therefore occur from wherever cattle urine is deposited, at grazing, in housing and yards, and from manure storage and spreading. In addition, emissions occur from urea- and ammonia-based inorganic fertilisers applied to land. Ammonia is of concern because of potential damage to sensitive ecosystems through acidification and eutrophication, and also because of its role in the formation of secondary particulates in the atmosphere (ammonium nitrate and ammonium sulphate) and their negative implications regarding human health (Erisman et al. 2007).

The $\mathrm{NH}_{3}$ flux from an emitting surface depends on a number of factors, including the $\mathrm{NH}_{3}$ concentration at the emitting surface, $\mathrm{pH}$, total exposed surface area (and surface area to volume ratio), temperature and the air flow above the emitting surface. Management, in addition to environmental conditions, can therefore have a great influence on emissions from livestock housing and manure storage (Sommer et al. 2006), from manure application to land (Sommer et al. 2003) and from fertiliser applications (Sommer et al. 2004). Mitigation strategies are therefore generally aimed at reducing the overall emitting surface area, reducing the $\mathrm{NH}_{3}$ concentration at the emitting surface or reducing air flow at the emitting surface.

Agriculture is a significant source of anthropogenic $\mathrm{CH}_{4}$ emissions to the atmosphere, accounting for c. $40 \%$ of emissions in the UK (MacCarthy et al. 2011), with the dairy sector estimated to account for approximately one third of total agricultural emissions. Methane is a greenhouse gas, with a global warming potential of 25 times that of $\mathrm{CO}_{2}$, over a 100 year lifetime (Forster et al. 2007). The major source of $\mathrm{CH}_{4}$ emissions from the dairy sector is enteric fermentation in the rumen of cattle, whereby $\mathrm{CH}_{4}$ is a by-product of microbial carbohydrate degradation. Enteric emissions are influenced by the gross energy intake of the animal and the digestibility of that energy, with the energy intake in turn being dependant on the energy requirements of the animal for maintenance, production (milk and/or growth), pregnancy and activity. Mitigation strategies are aimed at directly inhibiting the methanogenic bacteria in the rumen, manipulating the microbial breakdown pathways in the rumen, manipulating the digestibility of the diet or maximising the proportion of energy intake over the lifetime of an animal ultimately being used for milk production.

Methane emissions also arise from manure management, deriving from the microbial breakdown of excreted volatile solids under anaerobic conditions. Key driving factors are temperature, manure composition and degree of anaerobicity, which will be influenced by management (Chadwick et al. 2011). Mitigation strategies are aimed at reducing storage duration and/or temperature, minimising anaerobic conditions or through capturing and utilising produced $\mathrm{CH}_{4}$.

Agriculture is also a major source of $\mathrm{N}_{2} \mathrm{O}$ emissions, accounting for c. $80 \%$ of emissions in the UK (MacCarthy et al. 2011), with the dairy sector estimated to account for approximately one fifth of total agricultural emissions. Nitrous oxide is a potent greenhouse gas, with a global warming potential of 297 times that of $\mathrm{CO}_{2}$, over a 100 year lifetime (Forster et al. 2007). Nitrous oxide emissions arise as products, or partial products, of the microbial processes of nitrification (conversion of ammonium to nitrate $\left[\mathrm{NO}_{3}^{-}\right]$) and denitrification (conversion of $\mathrm{NO}_{3}{ }_{3}^{-}$to dinitrogen gas $\left[\mathrm{N}_{2}\right]$, with intermediary products as nitrite $\left[\mathrm{NO}_{2}^{-}\right]$, nitric oxide $[\mathrm{NO}]$ and $\mathrm{N}_{2} \mathrm{O}$ ). Nitrification is essentially an 
T. Misselbrook et al. (2013) 22: 93-107

aerobic process, while denitrification occurs under anaerobic conditions. The key direct sources of $\mathrm{N}_{2} \mathrm{O}$ emission from dairy farming are from $\mathrm{N}$ amendments to the soil, either as inorganic fertiliser, manure applications, grazing excretal returns or crop residues, and the management of livestock manure during housing and during storage. Major influencing factors are the availability of $\mathrm{N}$ and $\mathrm{C}$, anaerobicity and, to a lesser extent, temperature. $\mathrm{A}$ proportion of $\mathrm{NO}_{3}^{-}$leached and $\mathrm{N}$ deposited to land is re-emitted as $\mathrm{N}_{2} \mathrm{O}$. These indirect losses of $\mathrm{N}_{2} \mathrm{O}$ are significant. Mitigation strategies for direct $\mathrm{N}_{2} \mathrm{O}$ emissions are aimed at reducing the availability of $\mathrm{N}$, particularly under anaerobic conditions (e.g. wet soils), and at impeding the microbial processes through the use of inhibitors. Mitigation of indirect losses of $\mathrm{N}_{2} \mathrm{O}$, for example via $\mathrm{NO}_{3}{ }^{-}$leaching, are aimed at optimising $\mathrm{N}$ supply for crop demand and minimising the risk of excess $\mathrm{N}$ in the soil.

\section{Emissions to ground and surface waters}

Sources of diffuse water pollution on dairy farms include the farm steading (uncollected seepage from buildings, manure stores, yards frequented by dirty equipment and livestock), tracks, and the land itself (via fertiliser and manure applications, livestock grazing on the grassland, and nutrient applications to and cultivation of maize or cereal land). The principal diffuse water pollutants are $\mathrm{NO}_{3}{ }^{-}$, ammonium, $\mathrm{P}$, sediment, pathogens and organic matter (which generates at oxygen demand in the water course) (Chadwick and Chen 2003).

As much as $60 \%$ of the $\mathrm{NO}_{3}^{-}$found in UK watercourses is thought to come from agriculture. It arises from excess $\mathrm{N}$ input from fertiliser, applied manure and excreta from grazing livestock that is not utilised by the grass or crop. Rainfall then leaches the $\mathrm{NO}_{3}$ through the soil profile to drains and into watercourses.

Ammonium is a cation and hence can be immobilised in the soil profile. It is also readily nitrified to $\mathrm{NO}_{3}^{-}$, so is generally only found in low concentrations below grasslands. However, it can be lost following rainfall events that result in rapid overland flow, or movement of slurry through cracks in the soil to drains. The effect of excess $\mathrm{N}$ in watercourses is to provide nutrients to algae and other aquatic plant life (eutrophication), resulting in excessive growth and potential algal blooms. Nitrite and $\mathrm{NH}_{3}$ are also found in drainage water and are toxic to freshwater fish.

Phosphorus is another nutrient that contributes to eutrophication of watercourses. The relative impact of the $\mathrm{N}$ or $\mathrm{P}$ leached to surface waters depends on their nature; in some ecosystems $\mathrm{N}$ is the first limiting nutrient for algae growth whereas in other systems P may be limiting. Phosphorus is immobilised on soil surfaces and complexes with organic matter and metals such as iron, and is held strongly within the soil profile. Most of the P applied to grasslands is found in the top soil layer, so it's main pathway to watercourses is via detachment of soil particles and colloids in storms followed by overland flow (or again via cracks in the soil to drains following a slurry application), in contrast to movement of $\mathrm{N}$ which can be vertical and horizontal. In general, temperate grassland may lose 1-3 kg total $\mathrm{P} \mathrm{ha}^{-1} \mathrm{year}^{-1}$ (depending on inputs), but an individual rainfall event following a slurry application could result in 'incidental' losses as high as this in just one storm (Preedy et al. 2001).

Phosphorus losses are associated with sediment transfers from agricultural land. Sediment is a pollutant per se, as it affects the spawning grounds of salmonids. Although arable land is known to be a large source of agricultural sediment, grasslands are also a source (Granger et al. 2010), which is exacerbated by grazing livestock under wet soil conditions. On dairy farms, land used for forage maize is a potential critical source for sediment (and P) erosion and transfer to watercourses, especially if late harvests coincide with wet soil conditions.

The organic matter in dairy slurry and dirty water can generate an oxygen demand if it finds its way into a watercourse. This biological oxygen demand (BOD) results in rapid proliferation of micro-organisms in the watercourse which respire rapidly, removing oxygen from the water - resulting in asphyxiation of aquatic life. The BOD of a typical dairy slurry is ca. 10,000 $\mathrm{mg} \mathrm{l}^{-1}$ (Chadwick and Chen 2003), and that of dirty water ranges from 200-1000 $\mathrm{mg} \mathrm{l}^{-1}$ (Cumby et al. 1999). The recommendation for treated effluent entering a watercourse is $20 \mathrm{mg} \mathrm{l}^{-1}$ (HMSO 1980 ), so any significant loss of slurry or dirty water into a river will have negative environmental impacts.

Livestock manures applied to agricultural land and faeces deposited during grazing are sources of a range of pathogenic organisms. For dairy farming, the key pathogens include Cryptosporidium and Campylobacter. Whilst specific pathogens are of key interest in terms of human health, it is the indicator species of $E$. coli and Intestinal Enterococci, known as faecal indicator organisms (FIOs) on which legislation is based (CEC 2006). The risks of FIO losses from livestock farms to watercourses has been explored (Chadwick et al. 2008b), and are greater from farms with a greater number of livestock, steeply sloping land, and limited slurry storage capacity (Oliver et al. 2009). However, risks are also affected by farmer attitudes. In some instances, the topography of a farm can act as a 'safety net', e.g. where flat land reduces the risk of transfers, even if a farmer has limited slurry storage capacity or is unaware of the consequences of injudicious management of livestock and their manures. 
Haygarth et al. (2005) introduced the concept of pollutant movement from source to the watercourse, via the source-mobilisation-delivery-impact model. This model lends itself to addressing mitigation of diffuse water pollutants at each stage. Thus the source can be reduced, either through e.g. application of less fertiliser nitrogen, or by applying it in frequent doses and not all at once - thus reducing the risk of excess nitrogen in the soil at risk of loss. Mobilisation is the process by which a pollutant starts its journey towards the watercourse, and can occur via detachment or solubilisation. So mitigation methods suitable to reduce mobilisation would include the use of a nitrification inhibitor with an ammonium-based fertiliser, the incorporation of slurry into a maize field, rather than leaving it on the soil surface, or the injection of slurry into grassland soils to avoid surface run-off, reduce $\mathrm{NH}_{3}$ emissions and avoid potentially harmful bacteria from coming into contact with the crop. Finally, delivery can be reduced by intercepting pollutant rich drainage or overland flow via e.g. a constructed wetland.

Guidance is supplied to farmers to protect watercourses from diffuse water pollution, e.g. the UK Joint Code of Practice (Defra 2009). In some countries legislation is in place to reduce the impact of agriculture on water quality, e.g. the EU Nitrates Directive (EC 1991) has resulted in individual member states developing action plans to reduce the $\mathrm{NO}_{3}$ - concentrations of vulnerable watercourses. The action plans include closed periods for the spreading of high available $\mathrm{N}$ content manures, e.g. dairy slurry, and set a maximum $\mathrm{N}$ loading for a farm, thus introducing a stocking rate limit. The EU has also introduced the Water Framework Directive (CEC 2000) to protect the ecological status of watercourses. This covers a wider range of pollutants than just $\mathrm{NO}_{3}{ }^{-}$, and governments are putting in place guidance to farmers to help them comply with strict targets on future ecological status of watercourses.

Through a greater knowledge of the behaviour of different water pollutants, mitigation methods can be developed that are method-centric and can tackle multiple pollutants, rather than addressing just one individual pollutant (Granger et al. 2010). It is also essential that guidance on choice of mitigation methods takes account of any secondary impacts, e.g. pollution swapping. Cuttle et al. (2006) produced a Mitigation Manual for Diffuse Water Pollutants. The 44 methods included management of land use, soil, fertilisers, manures, livestock and farm infrastructure, e.g. provision of bridges to allow livestock to ford streams to reduce sediment and pathogen transfers to water. This Mitigation Manual was provided to Catchment Sensitive Farming Officers to provide advice on practical methods which could be introduced on farms, and at what cost. It has recently been updated to include mitigation methods for greenhouse gas and $\mathrm{NH}_{3}$ emissions. Both guidance documents highlight the relevance of each method to different farming systems, expresses the potential effectiveness in reducing the target pollutant(s) and the secondary impacts on other pollutants, the indicative cost of introducing the method, its practicality and likely uptake.

\section{Potential mitigation methods}

Considerable research effort in recent years has been aimed at developing mitigation methods and strategies to reduce the environmental impact of agricultural production practices. Specifically for dairy farms, these include animal health, diet, crop nutrient management, grazing management and genetic improvement in both livestock and crops. These are discussed in more detail below, with some specific scenarios assessed using the SIMS ${ }_{\text {DAIRY }}$ model. Changing the intensity of production (defined by milk yield per cow) may be considered as a potential mitigation strategy; Hagemann et al. (2011) cite level of intensity as the main reason for differences in GHG emission per kg energy corrected milk across 45 dairy regions in 38 countries. However, this is not considered explicitly within this review as it is recognised that a range of dairy production systems and levels of intensity will exist for reasons of climate, resource availability and socio-economic considerations. Rather, it is the scope to which potential mitigation measures can be implemented, the efficiency of production improved and the environmental impact per litre of milk production reduced that is important across all of these systems.

\section{Livestock health}

Production losses as a consequence of animal ill health and/or poor fertility result in an increase in the environmental emissions per litre of milk produced. In particular, the proportion of replacement animals required in a herd (related to the average number of lactations per dairy cow) can have a significant effect on emission intensity. Garnsworthy (2004) showed that significant reductions in $\mathrm{CH}_{4}$ and $\mathrm{NH}_{3}$ emissions could be made through improvements to dairy cow fertility, by up to $24 \%$ and $17 \%$, respectively. 


\section{Dietary strategies}

Dairy diet manipulation can lead to reductions in enteric $\mathrm{CH}_{4}$ emissions, and in $\mathrm{N}$ and $\mathrm{P}$ excretion, while having no detrimental effect on productivity. Potential dietary manipulations include the use of dietary additives with specific inhibitory effects on rumen $\mathrm{CH}_{4}$ production, manipulation of the in-house diet composition, particularly with respect to protein content and form, and manipulation of the grazed sward composition.

A number of dietary additives have been assessed for their effectiveness in reducing enteric $\mathrm{CH}_{4}$ emissions, either by direct inhibition or depopulation of rumen methanogens or through encouraging alternative microbial pathways of removing rumen hydrogen (e.g. Martin et al. 2010, Cottle et al. 2011), but in vitro effects are often difficult to replicate in vivo (van Zijderveld et al. 2011) or are short-lived (Guan et al. 2006).

Dairy cow dietary $P$ intake is often in excess of requirements (e.g. Powell et al. 2002, O'Rourke et al. 2010) and improved matching of requirement in the diet can result in significant reductions in P excretion (Dou et al. 2002) without compromising production or fertility (Wu and Satter 2000). The subsequent reduction in environmental impact of excreted P was reported by O'Rourke et al. (2010), who observed a 63\% reduction in manure total P content from a $43 \%$ reduction in dietary $\mathrm{P}$, and a significant reduction in the $\mathrm{P}$ concentration in overland flow following manure application for manure from the low dietary $P$ treatment. However, the same authors also concluded that the time interval between manure application and the generation of overland flow has a greater impact on $\mathrm{P}$ losses than does varying the dietary $\mathrm{P}$ content.

Manipulating the protein content of the diet, both in terms of the amount and forms of the protein has been shown to have significant effects of the amount of $\mathrm{N}$ excreted by cattle. Many studies have shown the potential that reducing the crude protein (CP) content of the diet can have on N excretion (e.g. Kulling et al. 2001, Broderick 2003) and therefore subsequent losses of $\mathrm{N}$ to the environment. Misselbrook et al. (2005b) showed this for a lactating dairy cow diet with a CP content of $14 \%$ compared with one of $19 \%$ (with the same proportion and type of forage), but also showed the influence of including condensed tannins in the diet (through manipulation of forage type), with significant reductions in $\mathrm{NH}_{3}$ emissions from the cattle excreta without negatively impacting on milk production. Both dietary strategies had the effect of reducing urinary $\mathrm{N}$ excretion by the cattle, which is more susceptible to environmental losses, at least in the shorter term, than faecal $\mathrm{N}$.

Dietary manipulation at grazing relies on management of the sward composition. For example, the use of grass varieties with a high content of water soluble carbohydrate, so called high sugar grasses (HSG), can reduce $\mathrm{N}$ excretion by almost $20 \%$ (urinary $\mathrm{N}$ excretion by $29 \%$ ) in cattle through more efficient utilisation of the feed $\mathrm{N}$ in the rumen and enhance productivity (Miller et al. 2001, Moorby et al. 2006). In a recent trial, $\mathrm{CH}_{4}$ emissions from growing lambs grazing HSG were also shown to be reduced, by an absolute value of $20 \%$, when compared with lambs grazing a conventional ryegrass sward, and also showed increased intake values and live weight gain (IBERS 2010). Inclusion of red clover in the sward, with the protein-binding action of the polyphenol content (Jones et al. 1995), has been hypothesized to reduce $\mathrm{N}$ excretion, as shown empirically by Powell et al. (2009) particularly for urine $\mathrm{N}$ excretion, although results from a study by van Dorland et al. (2007) were less supportive.

\section{Model scenarios for diet manipulation}

Farm scale modelling enables the impact of dietary (and other) strategies on a number of potential production and pollutant outputs to be assessed and, in particular, highlight where trade-offs in impacts may have to be made. The farm scale model, SIMS ${ }_{\text {DAIRY }}$ (del Prado et al. 2011) was used to assess the impact of two dietary strategies: i) growing and feeding HSG (i.e. replacing conventional grass cultivars); and ii) restricting CP intake either through the increased use of forage maize produced on-farm or by just reducing $\mathrm{N}$ concentration in the concentrates diet (depending on intensity of dairy system). Given a user-defined herd structure and type, milk production target and diet profile (as proportion of the diet coming from grass silage, maize silage and concentrates) SIMS DAIRY $_{\text {simulates }}$ through several iterations the metabolic processes and $\mathrm{N}$ and $\mathrm{C}$ pathways at the animal level (this includes DM intake, energy and true protein requirements, rumen $\mathrm{CH}_{4}$ and $\mathrm{N}$ excretion in urine and dung), the $\mathrm{N}$ and $\mathrm{P}$ flows and $\mathrm{N}$ and $\mathrm{CH}_{4}$ losses at the manure handling level, including the stages from the excretion on a barn floor or open lot surface where it remains until it is removed, the storage of manure and the application of manure to the soils in the farm. Subsequently, SIMS $_{\text {DAIRY }}$ simulates on a monthly time-step the $\mathrm{N}$ turnover in soil after application of animal manure and slurry (or urine and dung deposited whilst grazing), which in combination with mineral fertilizer $\mathrm{N}$ management and soil and weather conditions affects both productivity and quality of grass or maize and losses of N. Forage area is adjusted according to the total grass and maize required and the productivity of grass 
and maize per hectare (once silage making and feeding losses are accounted for). Herd typologies were defined for a set of locations and intensity of production systems (intensive/fully-housed, medium, extended), with full details given in IBERS (2010). New (from associated experimental work in IBERS 2010) and existing (Miller et al. 2001) experimental information at the animal level were incorporated on the effect of different diets on enteric $\mathrm{CH}_{4}$ output, milk production and $\mathrm{N}$ excretion. The main changes were carried out to simulate the effect of HSG intake on milk yield and voluntary dry matter intake, both of which are enhanced by HSG (Miller et al. 2001). The empirical equations relating enteric $\mathrm{CH}_{4}$ production to dry matter intake (del Prado et al. 2011) were modified for the forage maize portion of the diet according to empirical evidence from IBERS (2010).

For the HSG scenarios (Fig. 1), overall greenhouse gas emissions were reduced by up to 19\% per litre of milk, through reductions in both $\mathrm{CH}_{4}$ and $\mathrm{N}_{2} \mathrm{O}$. Ammonia emissions per litre of milk were reduced by up to $22 \%$, mainly due to the combination of fewer hectares required to produce 1 litre of milk and also due to reductions in excreted $\mathrm{N}$ (particularly urine $\mathrm{N}$ ). Reductions in $\mathrm{N}$ excretion were also associated with reductions in $\mathrm{NO}_{\mathrm{x}}$ emissions, because of the smaller pool of inorganic N subject to nitrification. Nitrate leaching was not significantly affected. Despite the potential beneficial effect of HSG on greenhouse gas emissions, if reseeding is required more frequently than for conventional grass varieties (to ensure persistence of effect), then the reduction in emissions described above could be offset by an increase in soil $\mathrm{N}_{2} \mathrm{O}$ emissions, $\mathrm{CO}_{2}$ emissions from fossil fuel use associated with reseeding and a decrease in potential soil $\mathrm{C}$ storage.

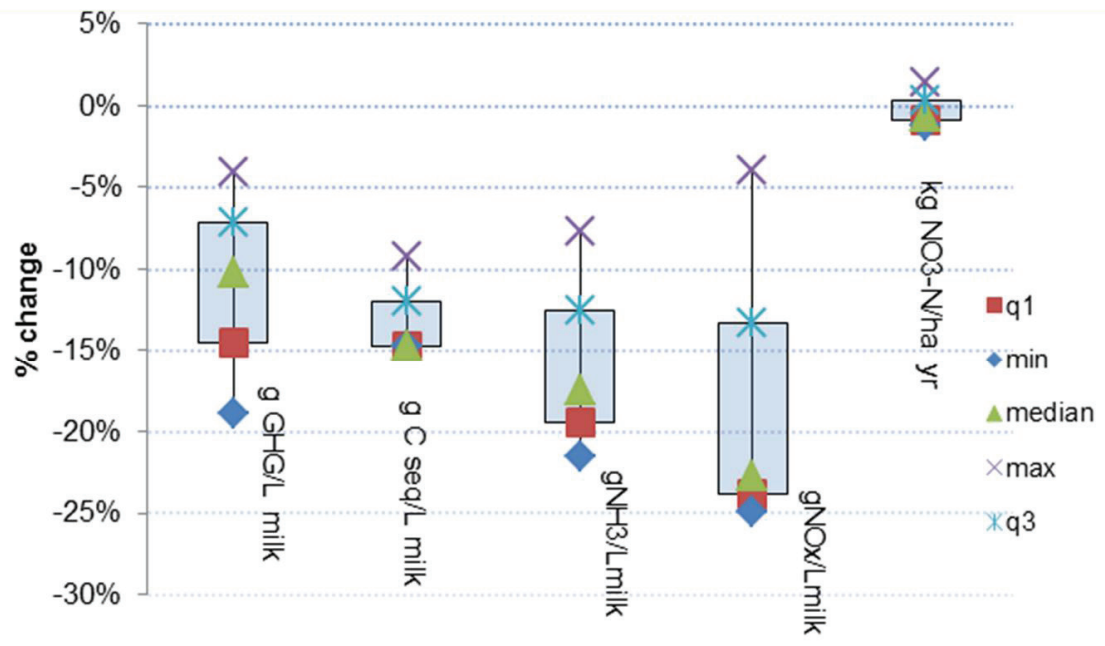

HSG

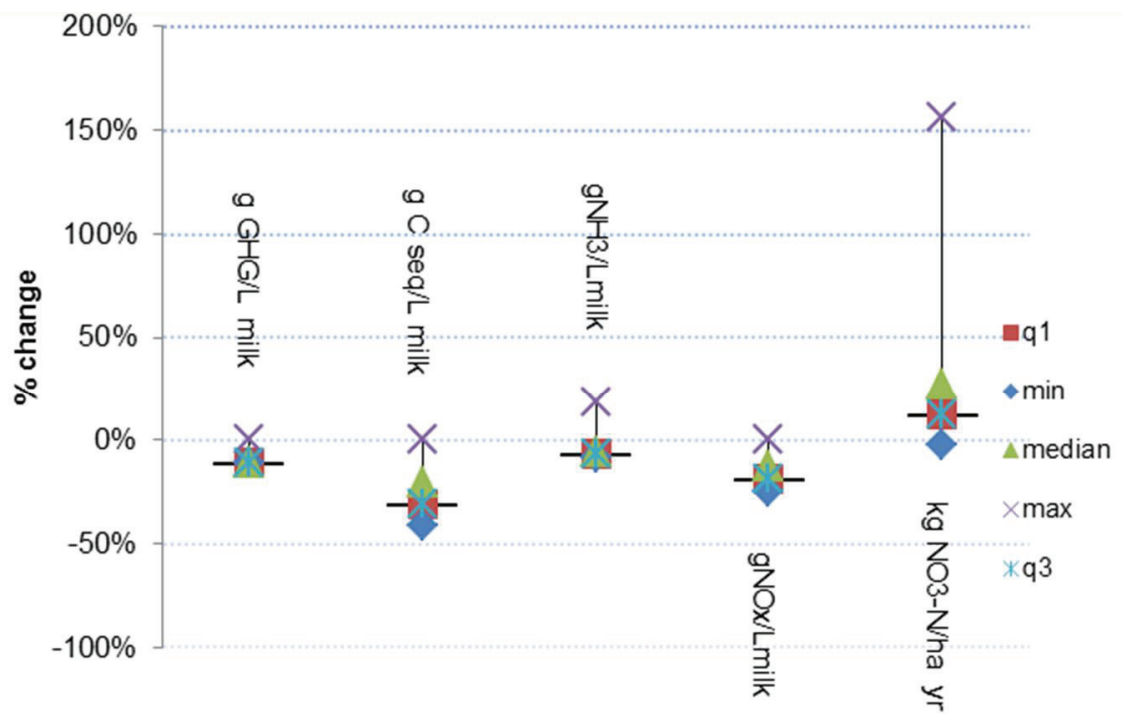

$-C P$

Fig. 1. Change (\%) in greenhouse gases (GHG), soil $\mathrm{C}$ storage, $\mathrm{NH}_{3}, \mathrm{NO}_{x}$ and $\mathrm{NO}_{3}$ - leaching for high sugar grasses (HSG) and reduced crude protein (CP) mitigation measures compared with baseline scenarios. Range reflects the model outputs across the range of locations and intensities of production. 
For lower CP intake scenarios (Fig. 1), overall greenhouse gas emissions were reduced by up to $11 \%$ per litre of milk. The details of the reduction depended on the intensity of the dairy system. For example, for the intensivefully housed system there was no reduction in enteric $\mathrm{CH}_{4}$ as the starch to fibre ratio was not altered in the diet, whereas $\mathrm{N}_{2} \mathrm{O}$ emissions were reduced because of reductions in $\mathrm{N}$ excretion, particularly in urine. For medium and extensive systems, enteric $\mathrm{CH}_{4}$ was reduced through a higher starch to fibre concentration in the diet (e.g. Beauchemin et al. 2008, Cottle et al. 2011), but soil $\mathrm{N}_{2} \mathrm{O}$ emissions were increased mainly caused by the replacement of grass with forage maize and the changes in manure application rates and timing. The proportion of land use change from grassland to maize determined the extent of the potential soil C loss. Results for $\mathrm{NH}_{3}$ and $\mathrm{NO}_{x}$ emissions very much depended on the intensity of the system, with a balance between reductions in $\mathrm{N}$ losses associated with lower $\mathrm{N}$ excretion and increases in $\mathrm{N}$ losses through indirect management changes after grassland conversion to maize. The main effect on $\mathrm{NO}_{3}$ - leaching losses was the conversion of grassland to maize and the associated changes in manure application timing.

\section{Crop nutrient management}

The soil nitrogen cycle is complex and potential crop uptake and losses to water and the atmosphere are very dependent on the form, rate and timing of the nitrogen inputs to the soil, soil texture and water status, and subsequent environmental conditions.

For inorganic nitrogen fertilisers, much can be achieved by attention to the type, timing and rate of application, ensuring that nitrogen supply matches crop requirements and is not applied in excess. Urea fertiliser, in particular, can be associated with large $\mathrm{NH}_{3}$ emissions of up to almost $50 \%$ of the applied $\mathrm{N}$ (Misselbrook et al. 2004), particularly if used under hot, dry conditions. Use under cooler conditions, at low application rates will be associated with much lower emissions (Misselbrook et al. 2004), and the incidence of rainfall soon after application will also reduce emissions, by up to $90 \%$, by ensuring rapid dissolution and transport of the urea into the soil matrix (SanzCobena et al. 2011). Smith et al. (2012) give some evidence that direct $\mathrm{N}_{2} \mathrm{O}$ emissions are less from urea fertiliser applications than from other fertiliser types, but indirect emissions associated with the greater $\mathrm{NH}_{3}$ emissions from urea would have been greater, so on balance there was no overall difference between fertiliser types. Emissions of $\mathrm{N}_{2} \mathrm{O}$ may increase disproportionately with fertiliser application rate, as shown for fertiliser applications to grassland at three sites in England by Cardenas et al. (2010) where the annual emission factor (proportion of total fertiliser $\mathrm{N}$ applied during the year lost as $\mathrm{N}_{2} \mathrm{O}$ ) was greater for higher cumulative annual application rates.

The use of forage legumes, such as clover in grass leys, offers the potential to offset applied inorganic $\mathrm{N}$ with biologically fixed N. Perceived disadvantages with the use of white clover are year to year variation in sward content and persistence (Frame et al. 1986). With greatly increasing fertiliser prices in recent years, there is a growing resurgence of interest in forage legumes, and a combination of improved traits through breeding and improved management practices may overcome some of these main perceived disadvantages (Parsons et al. 2011). Whilst the clover is growing, soil $\mathrm{N}_{2} \mathrm{O}$ emissions are generally smaller than those from inorganic fertilised soils as $\mathrm{N}$ originating from biological fixation is generally less available for nitrification and subsequent denitrification. Bacteria fix the $\mathrm{N}_{2}$ gas from the air into the $\mathrm{NH}_{4}{ }^{+}$ion that is largely used by the clover to form protein compounds. Once the legume crops are harvested, however, the protein compounds in residues are susceptible to decomposition and mineralisation to $\mathrm{NH}_{4}{ }^{+}$, which can then be nitrified and denitrified, leading to $\mathrm{N}_{2} \mathrm{O}$ emissions (Snyder et al., 2009). Nitrate leaching losses have been shown to be lower from grass-clover pastures than from fertilized grass (e.g. Hooda et al. 1998, Stopes et al. 2002), although may be similar for equivalent levels of N input (Sprosen et al. 1997, Scholefield et al. 2002).

Urease and nitrification inhibitors offer potential to reduce nitrogen emissions from fertiliser applications. Urease inhibitors, such as N-(n-butyl) thiophosphoric triamide (NBPT), delay the hydrolysis of urea to ammonium (Gill et al. 1999), thus delaying the opportunity for $\mathrm{NH}_{3}$ emissions to occur. Significant reductions (40-70\%) in $\mathrm{NH}_{3}$ emissions from urea fertiliser have been demonstrated using NBPT (e.g. Sanz-Cobena et al. 2008, Zaman et al. 2008, Chambers and Dampney 2009).

Nitrification inhibitors block the conversion of ammonium to $\mathrm{NO}_{3}^{-}$(Amberger 1989), thus the $\mathrm{N}$ is retained in the soil for longer in the ammonium form, thereby being less susceptible to losses via $\mathrm{NO}_{3}^{-}$leaching and denitrification. A recent meta-analysis of literature research results by Akiyama et al. (2010) suggested a mean reduction in $\mathrm{N}_{2} \mathrm{O}$ emissions of c. $40 \%$ through the use of nitrification inhibitors over a range of soil types and climatic conditions. A significant body of research has been conducted in New Zealand over the past 7-8 years assessing the 
use of nitrification inhibitors to reduce $\mathrm{NO}_{3}^{-}$leaching and $\mathrm{N}_{2} \mathrm{O}$ emissions from pasture systems, assessing reductions in emissions from urea fertiliser applications and urine returns by grazing livestock through the use of dicyandiamide (DCD). Reductions in $\mathrm{N}_{2} \mathrm{O}$ emission of up to $90 \%$ have been reported (de Klein and Eckard 2008), although Clough et al. (2007) proposed a more conservative $50 \%$ reduction to be applied to the emission factors used within the New Zealand inventory. Pasture yield increases are also reported from some studies, but not consistently (de Klein and Eckard 2008).

When using nitrification inhibitors with urea fertiliser or urine, there is the potential to reduce $\mathrm{N}_{2} \mathrm{O}$ emissions and $\mathrm{NO}_{3}{ }^{-}$leaching at the expense of increased $\mathrm{NH}_{3}$ emissions, as the $\mathrm{N}$ is being retained in the ammonium form for longer. The use of a double inhibitor (urease and nitrification) may prevent such trade-offs, but this has not been shown consistently (Zaman and Blennerhassett 2010).

There are opportunities to mitigate environmental impacts from manure management throughout the management continuum of housing, storage and spreading (Sommer and Hutchings 2001, Sommer et al. 2006, Chadwick et al. 2011). Opportunities are limited during the cattle housing phase, and depend also on choice of system. In general, a slurry-based system is associated with greater $\mathrm{NH}_{3}$ emissions throughout the management continuum than a straw-bedded deep litter system (Thorman et al. 2003). For a slurry-based housing system, there may be some potential in the rapid removal of excreta from fouled concrete areas to storage and in the use of urease inhibitors to reduce $\mathrm{NH}_{3}$ emissions (e.g. Varel et al. 1997, Misselbrook et al. 2006). For straw-bedded deep litter systems, $\mathrm{NH}_{3}$ emissions can be reduced through the targeted use of straw bedding to ensure sufficient bedding is supplied particularly to key locations which may be associated with higher emissions, such as near water troughs or feed areas (Gilhespy et al. 2009).

Options for reducing gaseous emissions during slurry storage include covering the store, the effectiveness of which will depend on the nature of the cover (e.g. Sommer et al. 1993, Blanes-Vidal et al. 2009, van der Zaag et al. 2010b) with natural crust formation providing some mitigation (Misselbrook et al. 2005a, Petersen et al. 2005). Anaerobic digestion of slurries can reduce $\mathrm{CH}_{4}$ emissions if the gas is properly captured and utilised, but increased availability of $\mathrm{N}$ in the digestate may increase losses of $\mathrm{NH}_{3}, \mathrm{~N}_{2} \mathrm{O}$ and $\mathrm{NO}_{3}$ - leaching during subsequent storage and application to land if not properly managed. Minimising slurry storage during warmer months will reduce $\mathrm{CH}_{4}$ emissions (van der Zaag et al. 2010a) and $\mathrm{NH}_{3}$ emissions (Sommer et al. 2006). Covering and compaction of farmyard manure heaps can decrease gaseous emissions (Chadwick 2005), although may not be widely viewed as a practical measure.

As with inorganic fertilisers, rate and timing of application are important in managing the environmental impact of manure applications to land. Smith et al. (2002) showed a very clear relationship between $\mathrm{NO}_{3}^{-}$leaching, crop $\mathrm{N}$ uptake and timing of application for slurry applications to freely draining soils in England, with up to $50 \%$ of applied $\mathrm{N}$ being lost via leaching and largest losses from applications in the September to November period. Application technique has a large effect on $\mathrm{NH}_{3}$ losses following slurry application, and significant reductions can be achieved through using slurry application techniques designed to minimise the emitting surface area and/or encourage slurry transfer to the soil matrix. Compared with surface broadcast application, reduction in emission of the order of $50-80 \%$ can be achieved using shallow injection, $40-60 \%$ using trailing shoe (designed for applications to grassland) and $10-40 \%$ using band spreading (more suitable for use in growing crops) (e.g. Misselbrook et al. 2002). Emissions may be further reduced by applying slurry beneath a more developed crop canopy, using band spreading (to arable crops) or trailing shoe (to grassland) application, where the combined effects of reduced air speed and temperature at the ground surface and the direct uptake of emitted $\mathrm{NH}_{3}$ by the crop canopy reduce emissions significantly compared to slurry applied to a bare surface (Thorman et al. 2008). Slurry application by trailing shoe to grassland can increase the window of opportunity for applications to be made; Laws and Pain (2002) and Laws et al. (2002) showed that grazing or silage harvesting could be made sooner after slurry application with this technique, compared with surface broadcast application, with no detrimental effects. The effect of slurry application technique on $\mathrm{N}_{2} \mathrm{O}$ emissions is less clear, with some reports of increasing emissions (e.g. Flessa and Beese 2000, Wulf et al. 2002, Velthof et al. 2003), which might be expected in particular for slurry injection where the anaerobic conditions in the injection slots with high available nitrogen and carbon concentrations would favour denitrification, and other reports of no net increase when compared with surface broadcast application (e.g. Sommer et al. 1996, Vallejo et al. 2005). 


\section{Model scenarios for nutrient management}

Nutrient management scenarios, specifically aimed at mitigating greenhouse gas emissions through improvements in fertilisation management, were evaluated in a modelling study using SIMS $_{\text {DAIRY }}$ (del Prado et al. 2010). The scenarios consisted of firstly, optimisation of mineral fertiliser $\mathrm{N}$ application rates and timing, and secondly, the use of nitrification inhibitors. Mineral fertilizer $\mathrm{N}$ use (rate and timing) was optimised using the in-built routine within SIMS $_{\text {DAIRY }}$ according to one of three criteria: (i) to maximise the efficiency ratio (defined as $\mathrm{kg} \mathrm{N}$ in herbage per $\mathrm{kg}$ $\mathrm{N}$ loss (Brown et al. 2005); (ii) to maximize annual herbage $\mathrm{N}$ production; or (iii) to meet a field-specific target for annual herbage $\mathrm{N}$ production equal to that of the baseline farm. Values were averaged for a range of farms differing in site conditions and nutrient use intensity.

Tactically matching the plant $\mathrm{N}$ requirements to the rate and temporal distribution of mineral $\mathrm{N}$ fertiliser through $\mathrm{SIMS}_{\text {DAIRY }}$ 's optimisation led to a reduction in overall $\mathrm{N}$ losses. For example, $\mathrm{NH}_{3}$ emissions were reduced by about $10 \%, \mathrm{NO}_{x}$ by $97 \%$ and $\mathrm{NO}_{3}^{-}$leaching by $6-14 \%$ per litre of milk produced. Denitrification losses were also decreased but site conditions greatly influenced the form of $\mathrm{N}$ loss (i.e. as $\mathrm{N}_{2} \mathrm{O}$ or $\mathrm{N}_{2}$ ). Nitrogen optimisation for the drier site with light soils was carried out favouring fertilisation applications at weather conditions that promoted smaller $\mathrm{N}_{2}$ losses but large $\mathrm{N}_{2} \mathrm{O}: \mathrm{N}_{2}$ ratios. As observed in a previous study by del Prado and Scholefield (2008), the optimised fertiliser distributions were achieved by lower annual rates of inorganic $\mathrm{N}$ fertilisers and higher relative rates in early spring. Lowering the total annual fertiliser rate also reduced the indirect pre-farm $\mathrm{CO}_{2}$ emission due to fertiliser manufacture.

Use of white clover in grass leys as a substitute for inorganic fertiliser $\mathrm{N}$ was one of the main differences between a conventional and organic dairy farm in a simulation by del Prado et al. (2011) using SIMS DAIRY $_{\text {. Greenhouse gas }}$ emissions per litre of milk were lower by $11-25 \%$, although differences in C sequestration, with the organic system assumed to be ploughed and reseeded every 5 years to ensure persistence of clover in the sward, were not taken into account. Ammonia emissions and concentration of $\mathrm{NO}_{3}{ }^{-}$in leachate were also lower for the organic system.

Nitrification inhibitors (e.g. DCD) added to both mineral $\mathrm{N}$ and manures applied to land reduced most forms of soil $\mathrm{N}$ losses. Whereas $\mathrm{N}_{2} \mathrm{O}$ and $\mathrm{NO}_{3}^{-}$leaching were reduced up to 55 and $40 \%$, respectively, emissions of $\mathrm{NO}_{x}$ and $\mathrm{NH}_{3}$ were not substantially affected. Nitrous oxide, for example, was greatly reduced as a consequence of a simulated increase in plant $\mathrm{N}$ use efficiency and a reduction in the rate of nitrification (and, therefore, subsequent denitrification). Greater reductions in emissions were achieved for drier soil conditions. The mitigation of $\mathrm{N}_{2} \mathrm{O}$ emissions was also greater in light-textured soils than in heavy-textured soils, which reflects, at least indirectly, the more effective nitrification inhibition found by experimental evidence in lighter soils with low organic matter content (e.g. Sahrawat and Keeney 1985).

\section{Grazing management}

Dairy farms demonstrate a number of different strategies in terms of grazing management, ranging from year round grazing (where climate and soil conditions allow) to year round housing for all or part of the herd. Webb et al. (2005) discussed the trade-off between grazing strategies in terms of $\mathrm{NO}_{3}$ - leaching losses, expected to be greater from grazing livestock from the high $\mathrm{N}$ intensity urine patches, and $\mathrm{NH}_{3}$ emissions, expected to be greater from housed livestock through the manure management continuum. They concluded that for a conventional UK system of approximately 6 months housing, extending the grazing season by one month in each of the spring and autumn periods reductions in $\mathrm{NH}_{3}$ emissions would be more than offset by increases in $\mathrm{NO}_{3}$ - leaching in terms of total $\mathrm{N}$ loss. Recent research has indicated that increasing the housing period can reduce $\mathrm{N}_{2} \mathrm{O}$ emissions at the farm level, both from indirect and direct emissions by about 10\% (e.g. de Klein et al. 2006, Luo et al. 2008). However, pre-farm $\mathrm{CO}_{2}$ emissions from mineral fertiliser manufacture increased substantially due to a shift towards more forage area needed for grass for conservation and hence more total mineral fertiliser needed. Using SIMS $_{\text {DAIRY }}$ del Prado et al. (2010) suggested that reducing grazing during the wetter parts of the season (by c. two months) reduced GHG emissions per litre of milk. Increasing the housing period can reduce $\mathrm{N}_{2} \mathrm{O}$ emissions, especially through a more uniform return of excreta via managed manure compared with very localized urine returns deposited by grazing (Oenema et al. 2006). There is also more potential for improved ration formulation when animals are housed and there is greater control over diet (Chadwick et al. 2008a), although there may be negative impacts on welfare and fertility (Marley et al. 2010, Mee 2012).

Model outputs are very dependent on system conditions (production system, soil and climatic conditions). For example del Prado et al. (unpublished data) showed that simulations of UK dairy farms under projections of future climate change scenarios resulted in more productive farms for most future time-slices and for most regions 
of the UK, mainly caused by a longer grass growing season. One proposed potential adaptation measure is to increase the grazing season by this extra growing season time (e.g. one month). The implications on other pollution $\mathrm{N}$ and $\mathrm{C}$ losses were not consistent across all regions. For example, for the South West UK region in the 2020s time-slice this adaptation measure implied pollution swapping between $\mathrm{N}$ emissions to water and to air (Fig. 2). There were much larger $\mathrm{NO}_{3}{ }_{3}^{-}$leaching losses than in the un-adapted scenarios and slightly larger $\mathrm{N}_{2} \mathrm{O}$ emissions and enteric $\mathrm{CH}_{4}$ emissions. Methane from manure management would be greatly reduced by requiring smaller storage volumes of manures. Overall net greenhouse gas emissions (as $\mathrm{kg} \mathrm{CO}_{2} \mathrm{eq} \mathrm{l}^{-1}$ milk) were reduced by increasing the grazing season, despite a small increase in enteric $\mathrm{CH}_{4}$ emissions, as were $\mathrm{NH}_{3}$ and $\mathrm{NO}_{\mathrm{x}}$ emissions. The net farm income and the other socio-economic scores all improved. Milk quality, for example, improved because of the shift to a larger proportion of fresh grass (grazed) over silage in the forage diet, associated with a better profile of polyunsaturated fatty acids in the milk. Animal welfare scores improved because of implied reduction in lameness and on the social structure of the cattle. Feeding cows mainly on fermented herbage (silage) also poses increased risks, which are principally generated by undesirable microorganisms (e.g. Listeria), undesirable chemicals (mycotoxins), and excess acidity (Wilkinson 1999).

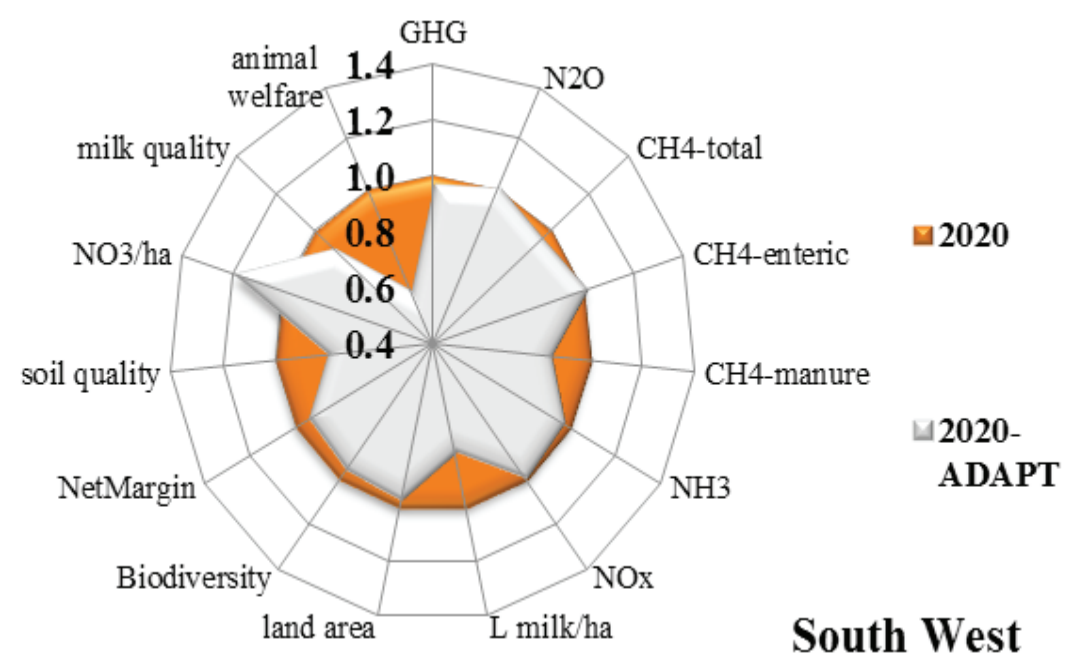

Fig. 2. Comparison between simulated results in terms of $\mathrm{N}, \mathrm{C}$ pollution and other socio-economic parameters (e.g. biodiversity, animal welfare, soil quality, economics) between un-adapted and adapted (one extra grazing month) dairy farm in the South West UK (2020). Values for the adapted scenario $<1$ indicate an improvement over the baseline scenario.

\section{Genetic potential}

Genetic improvement of livestock is a particularly effective technology, producing permanent and cumulative changes in performance. Wall et al. (2010) discuss the use of genetic selection tools for breeding schemes with the aims of improving productivity and efficiency and, potentially, selecting for inherently low $\mathrm{CH}_{4}$ emitting animals, although it is important that this selection is on the basis of multiple traits including feed efficiency, particularly for predominantly forage-fed animals, and yield to ensure that gains are realised as reduced emissions per unit product. Improvements in fertility would lead to a reduction in the required number of replacement animals, as discussed previously. However, it should be noted that dairy cows must breed to lactate and a reduction in total livestock numbers can only be achieved with improved fertility in dairy cows if a greater proportion of the dairybred calves can replace beef-cow calves, i.e. through the use of a beef bull.

Improved $\mathrm{N}$ use efficiency by grass varieties is an on-going aim of breeding programmes. However, while this may result in lower $\mathrm{N}$ losses though reduction in fertiliser requirement, an enhanced grass $\mathrm{CP}$ content could increase $\mathrm{N}$ excretion by cattle, thereby leading to increased losses from grazing returns and manure management (del Prado et al. 2010). Breeding for increased polyunsaturated fatty acid content, potentially decreasing enteric $\mathrm{CH}_{4}$ emissions may be another aim, although Dewhurst et al. (2001) noted that genetic variation in this trait is small compared with variation through the growing season. Other plant changes may involve traits in the shoot to root biomass 
ratio or plants with exudates capable of altering the mineralisation rate from decaying biomass remaining after harvest or grazing. Both measures have potential trade-offs between N forms lost (del Prado and Scholefield 2008).

\section{Combinations of measures}

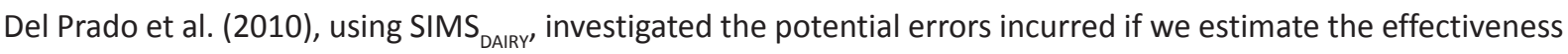
of GHG mitigation measures in combination compared with studies where the effectiveness of each method applied singly is simply added together. This latter, linear approach obviously ignores many of the potential synergies that may occur when applying different methods affecting soil, plant and/or animal components of the farm system. For example, the additive effect on farm level GHG emissions of a dietary measure to reduce $\mathrm{N}$ excretion by cattle and the use of a nitrification inhibitor to reduce $\mathrm{N}_{2} \mathrm{O}$ emissions from manure application to land will be greater than if the two are used in combination, as the dietary measure will reduce the size of the $\mathrm{N}$ pool on which the inhibitor is acting. Assessing measures singly also ignores the fact that some mitigation options may be mutually exclusive. The extent to which mitigation methods target processes that are interrelated is key to estimating the effectiveness of combined mitigation methods. The results from the del Prado et al. (2010) study indicated that for the measures considered in the scenario, the overall impact of applying a combination of measures was less than the simple addition of the effect of the measures applied singly.

\section{Conclusions}

Dairy production undoubtedly impacts upon the environment, particularly through emissions of $\mathrm{NH}_{3}$ and greenhouse gases to the atmosphere and transfers of pollutants to water. Research has improved our knowledge of the pollutant transfer processes and enabled the (on-going) development of a range of mitigation measures. However, it must be accepted that within the complex biological systems involved in dairy production, the complete elimination of environmental impacts is impossible.

Most of the mitigation measures discussed in this paper are associated with systemic improvements in the efficiency of production in dairy systems, rather than specific technological fixes (although these may also have a place). Much can be achieved through attention to livestock health, matching dietary requirements with supply, attention to the quantity, timing and method of application of nutrients to forage crops and utilising advances made through genetic improvements. The relative impact of many of the mitigation measures is specific to the genetic potential, soil, climate and management system of a particular dairy farm and therefore the use of decision support tools to explore alternative scenarios, and identify site-specific optimum practices are recommended.

Areas where further research and development are required include on-going genetic improvements in livestock and plant traits, development of diets or additives which have a consistent and persistent inhibitory effect on $\mathrm{CH}_{4}$ production in the rumen, assessment of alternative plant species and varieties for inclusion in grazed and ensiled forages, cost-effective delivery mechanisms for using urease and nitrification inhibitors, and a more complete accounting for the effects of silage production and management on forage quality in existing farm-scale models.

\section{Acknowledgements}

Agustin del Prado is funded by the projects from the Spanish National R+D+i Plan (CGL2009-10176) and the Department of Education, Universities and Research of the Basque Country (PC2010-33A).

\section{References}

Akiyama, H., Yan, X. \& Yagi, K. 2010. Evaluation of effectiveness of enhanced-efficiency fertilizers as mitigation options for $\mathrm{N}_{2} \mathrm{O}$ and NO emissions from agricultural soils: meta-analysis. Global Change Biology 16: 1837-1846.

Amberger, A. 1989. Research On dicyandiamide as a nitrification inhibitor and future outlook. Communications in Soil Science and Plant Analysis 20: 1933-1955.

Beauchemin, K.A., Kreuzer, M., O’Mara, F. \& McAllister, T.A. 2008. Nutritional management for enteric methane abatement: a review. Australian Journal of Experimental Agriculture 48: 21-27.

Blanes-Vidal, V., Hansen, M.N. \& Sousa, P. (2009). Reduction of odor and odorant emissions from slurry stores by means of straw covers. Journal of Environmental Quality 38: 1518-1527.

Broderick, G.A. 2003. Effects of varying dietary protein and energy levels on the production of lactating dairy cows. Journal of Dairy Science 86: 1370-1381. 
T. Misselbrook et al. (2013) 22: 93-107

Brown, L., Scholefield, D., Jewkes, E.C., Lockyer, D.R. \& del Prado, A. 2005. NGAUGE: A decision support system to optimise N fertilisation of British grassland for economic and environmental goals. Agriculture Ecosystems \& Environment 109: 20-39.

Cardenas, L.M., Thorman, R., Ashlee, N., Butler, M., Chadwick, D., Chambers, B., Cuttle, S., Donovan, N., Kingston, H., Lane, S., Dhanoa, M.S. \& Scholefield, D. 2010. Quantifying annual $\mathrm{N}_{2} \mathrm{O}$ emission fluxes from grazed grassland under a range of inorganic fertiliser nitrogen inputs. Agriculture Ecosystems \& Environment 138: 356-356.

CEC 2000. Council of the European Communities. Council Directive 200/60/EC of the European Parliament and of the council of 23 October 2000 establishing a framework for community action in the field of water policy. Official Journal of the European Union L327: 1-72.

CEC 2006. Council Directive 2006/7/EC of the European Parliament and of the council of 15 February 2006 concerning the management of bathing water quality and repealing Directive 76/160/EEC. Official Journal of the European Union L64: 37-51.

Chadwick, D.R. 2005. Emissions of ammonia, nitrous oxide and methane from cattle manure heaps: effect of compaction and covering. Atmospheric Environment 39: 787-799.

Chadwick, D.R, Chambers, B.J., Crabtree, R., Anthony, S. \& Harris, D. 2008a. Benefits and Pollution Swapping: cross-cutting issues for diffuse pollution mitigation. In: Crighton, K. \& Audsley, R. (eds.). Land Management in a Changing Environment. SAC and SEPA (Agriculture and the Environment, VII) p. 41-47.

Chadwick D.R. \& Chen S. 2003. Manures. In: Haygarth P.M. \& Jarvis S.C. (eds.). Agriculture, Hydrology and Water Quality. pp.57-82. CAB International, Wallingford UK.

Chambers, B. \& Dampney, P. 2009. Nitrogen efficiency and ammonia emissions from urea-based and ammonium nitrate fertilisers. Proceedings - International Fertiliser Society, Issue 657, 1-20.

Chadwick, D., Fish, R., Oliver, D.M., Heathwaite, L., Hodgson, C. \& Winter, M. 2008b. Management of livestock and their manure to reduce the risk of microbial transfers to water - the case for an interdisciplinary approach. Trends in Food Science \& Technology 19: 240-247.

Chadwick, D., Sommer, S., Thorman, R., Fangueiro, D., Cardenas, L., Amon, B. \& Misselbrook, T. 2011. Manure management: Implications for greenhouse gas emissions. Animal Feed Science and Technology 166-167: 514-531.

Clough, T.J., Di, H.J., Cameron, K.C., Sherlock, R.R., Metherell, A.K., Clark, H. \& Rys, G. 2007. Accounting for the utilization of a $\mathrm{N}_{2} \mathrm{O}$ mitigation tool in the IPCC inventory methodology for agricultural soils. Nutrient Cycling in Agroecosystems 78: 1-14.

Cottle, D.J., Nolan, J.V. \& Wiedemann, S.G. 2011. Ruminant enteric methane mitigation: a review. Animal Production Science 51: 491-514.

Cumby, T.R., Brewer, A.J. \& Dimmock, S.J. 1999. Dirty water from dairy farms, I: biochemical characteristics. Bioresource Technology 67: 155-160.

Cuttle, S.P., Macleod, C.J.A., Chadwick, D.R., Newell-Price, P., Harris, D., Shepherd, M.A., Chambers, B.J. \& Humphrey, R. 2006. An inventory of methods to control diffuse water pollution from agriculture. Report prepared as part of Defra Project ESO203. Cited 22 May 2012. Available on the Internet http://randd.defra.gov.uk/Default.aspx?Menu=Menu\&Module=More\&Location=None\&Proje ctID=13405\&FromSearch=Y\&Publisher=1\&SearchText=ES0203\&SortString=ProjectCode\&SortOrder=Asc\&Paging=10\#Description .

de Klein, C.A.M. \& Eckard, R.J. 2008. Targeted technologies for nitrous oxide abatement from animal agriculture. Australian Journal of Experimental Agriculture 48: 14-20.

de Klein, C.A.M., Smith, L.C. \& Monaghan, R.M. 2006. Restricted autumn grazing to reduce nitrous oxide emissions from dairy pastures in Southland, New Zealand. Agriculture Ecosystems \& Environment 112: 192-199.

Defra. 2009. Protecting Our Water, Soil and Air: A Code of Good Agricultural Practice. The Stationary Office, Norwich. ISBN 978 0112432845

del Prado, A., Chadwick, D., Cardenas, L., Misselbrook, T., Scholefield, D. \& Merino, P. 2010. Exploring systems responses to mitigation of GHG in UK dairy farms. Agriculture Ecosystems \& Environment 136: 318-332.

del Prado, A., Misselbrook, T., Chadwick, D., Hopkins, A., Dewhurst, R. J., Davison, P., Butler, A., Schroder, J. \& Scholefield, D. 2011. SIMS $_{\text {DARY }}$ : A modelling framework to identify sustainable dairy farms in the UK. Framework description and test for organic systems and N fertiliser optimisation. Science of The Total Environment 409: 3993-4009.

del Prado, A. \& Scholefield, D. 2008. Use of SIMS modelling framework system to compare the scope on the sustainability of a dairy farm of animal and plant genetic-based improvements with management-based changes. Journal of Agricultural Science 146: 195-211.

Dewhurst, R.J., Scollan, N.D., Youell, S.J., Tweed, J.K.S. \& Humphreys, M.O. 2001. Influence of species, cutting date and cutting interval on the fatty acid composition of grasses. Grass and Forage Science 56: 68-74.

Dou, Z.X., Knowlton, K.F., Kohn, R.A., Wu, Z.G., Satter, L.D., Zhang, G.Y., Toth, J.D. \& Ferguson, J.D. 2002. Phosphorus characteristics of dairy feces affected by diets. Journal of Environmental Quality 31: 2058-2065.

EC 1991. Council Directive 92/676/EEC on Nitrate in Drinking Water. Official Journal of the European Communities (91/676/EEC), Legislation 1375/1-1375/8, European Community, Brussels.

Erisman, J.W., Bleeker, A., Galloway, J. \& Sutton, M.S. 2007. Reduced nitrogen in ecology and the environment. Environmental Pollution 150: 140-149.

Flessa, H. \& Beese, F. 2000. Laboratory estimates of trace gas emissions following surface application and injection of cattle slurry. Journal of Environmental Quality 29: 262-268.

Forster, P., Ramaswamy, V., Artaxo, P., Berntsen, T., Betts, R., Fahey, D.W., Haywood, J., Lean, J., Lowe, D.C., Myhre, G., Nganga, J., Prinn, R., Raga, G., Schulz, M. \& van Dorland, R. 2007. Changes in atmospheric constituents and in radiative forcing. In: Solomon, S., Qin, D., Manning, M., Chen, Z., Marquis, M., Averyt, K.B., Tignor, M., Miller, H.L. (eds.). Climate Change 2007: the Physical Science Basis. Contribution of Working Group I to the Fourth Assessment Report of the Intergovernmental Panel on Climate Change. Cambridge, United Kingdom and New York, NY, USA: Cambridge University Press. p. 996. 
T. Misselbrook et al. (2013) 22: 93-107

Frame, J., Newbould, P. \& Brady, N.C. 1986. Agronomy of white clover. Advances in Agronomy 40: 1-88.

Garnsworthy, P.C. 2004. The environmental impact of fertility in dairy cows: a modelling approach to predict methane and ammonia emissions. Animal Feed Science and Technology 112: 211-223.

Gilhespy, S.L., Webb, J., Chadwick, D.R., Misselbrook, T.H., Kay, R., Camp, V., Retter, A.L. \& Bason, A. 2009. Will additional straw bedding in buildings housing cattle and pigs reduce ammonia emissions? Biosystems Engineering 102: 180-189.

Gill, J.S., Bijay Singh, Khind, C.S. \& Yadvinder Singh 1999. Efficiency of N-(n-butyl) thiophosphoric triamide in retarding hydrolysis of urea and ammonia volatilization losses in a flooded sandy loam soil amended with organic materials. Nutrient Cycling in Agroecosystems 53: 203-207.

Godfray, H.C.J., Beddington, J.R., Crute, I.R., Haddad, L., Lawrence, D., Muir, J.F., Pretty, J., Robinson, S., Thomas, S.M. \& Toulmin, C. 2010. Food Security: The Challenge of Feeding 9 Billion People. Science 327: 812-818.

Granger, S.J., Bol, R., Anthony, S., Owens, P.N., White, S.M. \& Haygarth, P.M. 2010. Towards a holistic classification of diffuse agricultural water pollution from intensively managed grasslands on heavy soils. Advances in Agronomy 105: 83-115.

Guan, H., Wittenberg, K.M., Ominski, K.H. \& Krause, D.O. 2006. Efficacy of ionophores in cattle diets for mitigation of enteric methane. Journal of Animal Science 84: 1896-1906.

Hagemann, M., Hemme, T., Ndambi, A., Alqaisi, O. \& Sultana, M. N. 2011. Benchmarking of greenhouse gas emissions of bovine milk production systems for 38 countries. Animal Feed Science and Technology 166-67: 46-58.

Haygarth, P.M., Condron, L.M., Heathwaite, A.L., Turner, B.L. \& Harris, G.P. 2005. The phosphorus transfer continuum: Linking source to impact with an interdisciplinary and multi-scaled approach. Science of The Total Environment 344: 5-14.

HMSO 1980. 5 Day Biochemical Oxygen Demand $\left(B O D_{5}\right)$. Second Edition. Methods for Examination of Waters and Associated Materials. Royal Commission. p. 35.

Hooda, P.S., Moynagh, M., Svoboda, I.F. \& Anderson, H.A. 1998. A comparative study of nitrate leaching from intensively managed monoculture grass and grass-clover pastures. Journal of Agricultural Science 131: 267-275.

IBERS. 2010. Ruminant nutrition regimes to reduce methane and nitrogen emissions. Final report for Defra project AC0209. Cited 25 Feb 2012. Available on the Internet: http://randd.defra.gov.uk/Document.aspx?Document=AC0209_10114_FRP.pdf

Jones, B.A., Muck, R.E. \& Hatfield, R.D. 1995. Red clover extracts inhibit legume proteolysis. Journal of the Science of Food and Agriculture 67: 329-333.

Kulling, D.R., Menzi, H., Krober, T.F., Neftel, A., Sutter, F., Lischer, P. \& Kreuzer, M. 2001. Emissions of ammonia, nitrous oxide and methane from different types of dairy manure during storage as affected by dietary protein content. Journal of Agricultural Science 137: 235-250.

Laws, J.A. \& Pain, B.F. 2002. Effects of method, rate and timing of slurry application to grassland on the preference by cattle for treated and untreated areas of pasture. Grass and Forage Science 57: 93-104.

Laws, J.A., Smith, K.A., Jackson, D.R. \& Pain, B.F. 2002. Effects of slurry application method and timing on grass silage quality. Journal of Agricultural Science 139: 371-384.

Luo, J., Ledgard, S.F., de Klein, C.A.M., Lindsey, S.B. \& Kear, M. 2008. Effects of dairy farming intensification on nitrous oxide emissions. Plant and Soil 309: 227-237.

MacCarthy J., Brown K., Webb N., Passant N., Thistlethwaite G., Murrells T., Watterson J., Cardenas L., Thomson A. \& Pang Y. 2011. UK Greenhouse Gas Inventory, 1990 to 2009: Annual Report for submission under the Framework Convention on Climate Change. AEA, UK. Report AEA/ENV/R/3150. Cited 15 April 2011. Available on the Internet: http://naei.defra.gov.uk/reports.php.

Marley, C.L., Weller, R.F., Neale, M., Main, D.C.J., Roderick, S. \& Keatinge, R. 2010. Aligning health and welfare principles and practice in organic dairy systems: a review. Animal 4: 259-271.

Martin, C., Morgavi, D.P. \& Doreau, M. 2010. Methane mitigation in ruminants: from microbe to the farm scale. Animal 4:351-365.

Mee, J.F. 2012. Reproductive issues arising from different management systems in the dairy industry. Reproduction in Domestic Animals 47: 42-50.

Miller, L.A., Moorby, J.M., Davies, D.R., Humphreys, M.O., Scollan, N.D., MacRae, J.C. \& Theodorou, M.K. 2001. Increased concentration of water-soluble carbohydrate in perennial ryegrass (Lolium perenne L.): milk production from late-lactation dairy cows. Grass and Forage Science 56: 383-394.

Misselbrook, T.H., Brookman, S.K.E., Smith, K.A., Cumby, T.R., Williams, A.G. \& McCrory, D.F. 2005a. Crusting of stored dairy slurry to abate ammonia emissions: pilot-scale studies. Journal of Environmental Quality 34: 411-419.

Misselbrook, T.H., Cape, J.N., Cardenas, L.M., Chadwick, D.R., Dragosits, U., Hobbs, P.J., Nemitz, E., Reis, S., Skiba, U. \& Sutton, M.A. 2011. Key unknowns in estimating atmospheric emissions from UK land management. Atmospheric Environment 45: 1067-1074.

Misselbrook, T.H., Powell, J.M., Broderick, G.A. \& Grabber, J.H. 2005b. Dietary manipulation in dairy cattle: laboratory experiments to assess the influence on ammonia emissions. Journal of Dairy Science 88: 1765-1777.

Misselbrook, T.H., Smith, K.A., Johnson, R.A. \& Pain, B.F. 2002. Slurry application techniques to reduce ammonia emissions: Results of some UK field-scale experiments. Biosystems Engineering 81: 313-321.

Misselbrook, T.H., Sutton, M.A. \& Scholefield, D. 2004. A simple process-based model for estimating ammonia emissions from agricultural land after fertilizer applications. Soil Use and Management 20: 365-372.

Misselbrook, T.H., Webb, J. \& Gilhespy, S.L. 2006. Ammonia emissions from outdoor concrete yards used by livestock - quantification and mitigation. Atmospheric Environment 40: 6752-6763.

Moorby, J.M., Evans, R.T., Scollan, N.D., Macraet, J.C. \& Theodorou, M.K. 2006. Increased concentration of water-soluble carbohydrate in perennial ryegrass (Lolium perenne L.). Evaluation in dairy cows in early lactation. Grass and Forage Science 61: 52-59. 
T. Misselbrook et al. (2013) 22: 93-107

O'Rourke, S.M., Foy, R.H., Watson, C.J., Ferris, C.P. \& Gordon, A. 2010. Effect of varying the phosphorus content of dairy cow diets on losses of phosphorus in overland flow following surface applications of manure. Journal of Environmental Quality 39: 2138-2146.

Oenema, O., Janssen, B.H., Smaling, E. \& Hoffland, E. 2006. Nutrient management in tropical agroecosystems. Agriculture Ecosystems \& Environment 116: 1-3.

Oliver, D.M., Fish, R.D., Hodgson, C.J., Heathwaite, A.L., Chadwick, D.R. \& Winter, M. 2009. A cross-disciplinary toolkit to assess the risk of faecal indicator loss from grassland farm systems to surface waters. Agriculture Ecosystems \& Environment 129: 401-412.

Parsons, A.J., Edwards, G.R., Newton, P.C.D., Chapman, D.F., Caradus, J.R., Rasmussen, S. \& Rowarth, J.S. 2011. Past lessons and future prospects: plant breeding for yield and persistence in cool-temperate pastures. Grass and Forage Science 66: 153-172.

Passant, N.R., Wagner, A., Murrells, T.P., Li, Y., Okamura, S., Thistlethwaite, G., Walker, H.L., Walker, C., Whiting, R., Sneddon, S., Stewart, R.A., Brophy, N.C.J., MacCarthy, J., Tsagatakis, I. \& Bush, T. 2011. UK Informative Inventory Report (1970 to 2009): Annual Report for submission under the UNECE-Convention on Long-Range Transboundary Air Pollution. AEA, UK. Cited 15 March 2011. Available on the Internet: http://naei.defra.gov.uk/reports.php.

Petersen, S.O., Amon, B. \& Gattinger, A. 2005. Methane oxidation in slurry storage surface crusts. Journal of Environmental Quality 34: 455-461.

Pilgrim, E.S., Macleod, C.J.A., Blackwell, M.S.A., Bol, R., Hogan, D.V., Chadwick, D.R., Cardenas, L., Misselbrook, T.H., Haygarth, P.M., Brazier, R.E., Hobbs, P., Hodgson, C., Jarvis, S., Dungait, J., Murray, P.J. \& Firbank, L.G. 2010. Interactions among agricultural production and other ecosystem services delivered from European temperate grassland systems. Advances in Agronomy 109: 117-154.

Powell, J.M., Broderick, G.A., Grabber, J.H. \& Hymes-Fecht, U.C. 2009. Effects of forage protein-binding polyphenols on chemistry of dairy excreta. Journal of Dairy Science 92: 1765-1769.

Powell, J.M., Jackson-Smith, D B. \& Satter, L.D. 2002. Phosphorus feeding and manure nutrient recycling on Wisconsin dairy farms. Nutrient Cycling in Agroecosystems 62: 277-286.

Preedy, N., McTiernan, K., Matthews, R., Heathwaite, L. \& Haygarth, P. 2001. Rapid incidental phosphorus transfers from grassland. Journal of Environmental Quality 30: 2105-2112.

Sahrawat, K.L. \& Keeney, D.R. 1985. Perspectives for research on development of nitrification inhibitors. Communications in Soil Science and Plant Analysis 16: 517-524.

Sanz-Cobena, A., Misselbrook, T.H., Arce, A., Mingot, J.I., Diez, J.A. \& Vallejo, A. 2008. An inhibitor of urease activity effectively reduces ammonia emissions from soil treated with urea under Mediterranean conditions. Agriculture Ecosystems \& Environment 126: 243-249.

Sanz-Cobena, A., Misselbrook, T., Camp, V. \& Vallejo, A. 2011. Effect of water addition and the urease inhibitor NBPT on the abatement of ammonia emission from surface applied urea. Atmospheric Environment 45: 1517-1524.

Scholefield, D., Halling, M., Tuori, M., Isolahti, M., Soelter, U. \& Stone, A.C. 2002. Assessment of nitrate leaching from beneath forage legumes. In: Wilkins, R.J. \& Paul, C. (eds.) Legume Silages for Animal Production. Braunschweig: Bundesforschungsanstalt Landwirtschaft (FAL). p. 17-25.

Shaw, S.L., Mitloehner, F.M., Jackson, W., Depeters, E.J., Fadel, J.G., Robinson, P.H., Holzinger, R. \& Goldstein, A.H. 2007. Volatile organic compound emissions from dairy cows and their waste as measured by proton-transfer-reaction mass spectrometry. Environmental Science \& Technology 41: 1310-1316.

Smith, K.A., Beckwith, C.P., Chalmers, A.G. \& Jackson, D.R. 2002. Nitrate leaching following autumn and winter application of animal manures to grassland. Soil Use and Management 18: 428-434.

Smith, K.A., Dobbie, K.E., Thorman, R., Watson, C.J., Chadwick, D.R., Yamulki, S. \& Ball, B.C. 2012. The effect of N fertiliser forms on nitrous oxide emissions from UK arable land and grassland. Nutrient Cycling in Agroecosystems 93: 127-149.

Snyder, C.S., Bruulsema, T.W., Jensen, T.L. \& Fixen, P.E. 2009. Review of greenhouse gas emissions from crop production systems and fertilzer management effects. Agriculture Ecosystems \& Environment 133: 247-266.

Sommer, S.G., Christensen, B.T., Nielsen, N.E. \& Schjorring, J.K. 1993. Ammonia volatilization during storage of cattle and pig slurry - effect of surface cover. Journal of Agricultural Science 121: 63-71.

Sommer, S.G., Genermont, S., Cellier, P., Hutchings, N.J., Olesen, J.E. \& Morvan, T. 2003. Processes controlling ammonia emission from livestock slurry in the field. European Journal of Agronomy 19: 465-486.

Sommer, S.G. \& Hutchings, N.J. 2001. Ammonia emission from field applied manure and its reduction - invited paper. European Journal of Agronomy 15: 1-15.

Sommer, S.G., Sherlock, R.R. \& Khan, R.Z. 1996. Nitrous oxide and methane emissions from pig slurry amended soils. Soil Biology \& Biochemistry 28: 1541-1544.

Sommer, S.G., Schjoerring, J.K. \& Denmead, O.T. 2004. Ammonia emission from mineral fertilizers and fertilized crops. Advances in Agronomy 82: 557-622.

Sommer, S.G., Zhang, G.Q., Bannink, A., Chadwick, D., Misselbrook, T., Harrison, R., Hutchings, N. J., Menzi, H., Monteny, G.J., Ni, J.Q., Oenema, O. \& Webb, J. 2006. Algorithms determining ammonia emission from buildings housing cattle and pigs and from manure stores. Advances in Agronomy 89: 261-335.

Sprosen, M.S., Ledgard, S.F. \& Thom, E.R. 1997. Nitrate leaching is similar in $\mathrm{N}_{2}$-fixing grass-clover pasture and N-fertilised grassonly pasture at similar N inputs. Proceedings of the New Zealand Grassland Association 59: 125-128.

Stopes, C., Lord, E.I., Philipps, L. \& Woodward, L. 2002. Nitrate leaching from organic farms and conventional farms following best practice. Soil Use and Management 18: 256-263.

Thorman, R.E., Hansen, M.N., Misselbrook, T.H. \& Sommer, S.G. 2008. Algorithm for estimating the crop height effect on ammonia emission from slurry applied to cereal fields and grassland. Agronomy for Sustainable Development 28: 373-378. 
Thorman R.E., Harrison R., Cooke S.D., Chadwick D.R., Burston M. and Balsdon S.L. 2003. Nitrous oxide emissions from slurry- and straw-based systems for cattle and pigs in relation to emissions of ammonia. In: McTaggart I. \& Gairns L. (eds.). Proceedings of SAC/SEPA Conference on Agriculture, Waste and the Environment. Edinburgh 26-28 March 2002. p. 26-32.

Vallejo, A., Garcia-Torres, L., Diez, J.A., Arce, A. \& Lopez-Fernandez, S. 2005. Comparison of N losses ( $\mathrm{NO}_{3}{ }^{-}, \mathrm{N}_{2} \mathrm{O}$, NO) from surface applied, injected or amended (DCD) pig slurry of an irrigated soil in a Mediterranean climate. Plant and Soil 272: 313-325.

van Dorland, H.A., Wettstein, H.R., Leuenberger, H. \& Kreuzer, M. 2007. Effect of supplementation of fresh and ensiled clovers to ryegrass on nitrogen loss and methane emission of dairy cows. Livestock Science 111: 57-69.

van der Zaag, A.C., Gordon, R.J., Jamieson, R.C., Burton, D.L. \& Stratton, G.W. 2010a. Effects of winter storage conditions and subsequent agitation on gaseous emissions from liquid dairy manure. Canadian Journal of Soil Science 90: 229-239.

van Zijderveld, S.M., Dijkstra, J., Perdok, H.B., Newbold, J.R. \& Gerrits, W.J.J. 2011. Dietary inclusion of diallyl disulfide, yucca powder, calcium fumarate, an extruded linseed product, or medium-chain fatty acids does not affect methane production in lactating dairy cows. Journal of Dairy Science 94: 3094-3104.

van der Zaag, A.C., Gordon, R.J., Jamieson, R.C., Burton, D.L. \& Stratton, G.W. 2010b. Permeable synthetic covers for controlling emissions from liquid dairy manure. Applied Engineering in Agriculture 26: 287-297.

Varel, V.H., Nienaber, J.A. \& Byrnes, B.H. 1997. Urease inhibitors reduce ammonia emissions from cattle manure. In: Voermans, J.A.M \& Monteny, G.J. (eds.). Ammonia and Odour Emissions From Animal Production Facilities, Proceedings. Rosmalen: Nederlandse Vereniging Techniek Landbouw. p. 721-728.

Velthof, G.L., Kuikman, P.J. \& Oenema, O. 2003. Nitrous oxide emission from animal manures applied to soil under controlled conditions. Biology and Fertility of Soils 37: 221-230.

Wall, E., Simm, G. \& Moran, D. 2010. Developing breeding schemes to assist mitigation of greenhouse gas emissions. Animal 4: 366-376.

Webb, J., Anthony, S.G., Brown, L., Lyons-Visser, H., Ross, C., Cottrill, B., Johnson, P. \& Scholefield, D. 2005. The impact of increasing the length of the cattle grazing season on emissions of ammonia and nitrous oxide and on nitrate leaching in England and Wales. Agriculture Ecosystems \& Environment 105: 307-321.

Wilkinson, J.M. 1999. Silage and animal health. Natural Toxins 7: 221-232.

Wu, Z. \& Satter, L.D. 2000. Milk production and reproductive performance of dairy cows fed two concentrations of phosphorus for two years. Journal of Dairy Science 83: 1052-1063.

Wulf, S., Maeting, M. \& Clemens, J. 2002. Application technique and slurry co-fermentation effects on ammonia, nitrous oxide, and methane emissions after spreading: II. Greenhouse gas emissions. Journal of Environmental Quality 31: 1795-1801.

Zaman, M. \& Blennerhassett, J.D. 2010. Effects of the different rates of urease and nitrification inhibitors on gaseous emissions of ammonia and nitrous oxide, nitrate leaching and pasture production from urine patches in an intensive grazed pasture system. Agriculture, Ecosystems \& Environment 136: 236-246.

Zaman, M., Nguyen, M.L., Blennerhassett, J.D. \& Quin, B.F. 2008. Reducing $\mathrm{NH}_{3}, \mathrm{~N}_{2} \mathrm{O}$ and $\mathrm{NO}_{3}{ }^{-} \mathrm{N}$ losses from a pasture soil with urease or nitrification inhibitors and elemental S-amended nitrogenous fertilizers. Biology and Fertility of Soils 44: 693-705. 